\title{
Analysis on the distribution of zooplankton in tropical shallow urban lakes
}

\author{
Guangrong Chen ${ }^{1, *}$ \\ ${ }^{1}$ Guangdong Construction Polytechnic, Guanghua 2nd Road 638, GuangZhou, China
}

\begin{abstract}
The distribution characteristics of zooplankton in shallow urban lakes of Lingnan that in the tropics and subtropics were studied. The results showed that Brachionus, Trichocerea, and Lecane were dominant species of composition and abundance. The abundance of large Cladocera was low, which was affected by high water temperature, food restriction, and predation pressure of fish. Rotifera, small Cladocera, and Nauplius were the main zooplankton. Combined with the analysis of typical tropical shallow urban lakes, the dominant zooplankton tended to have a small individual population. It was expected to provide a reference for the ecological restoration of tropical shallow-water urban lakes.
\end{abstract}

\section{Introduction}

There had been some studies on zooplankton in some tropical regions of Asia, Africa, South America, and Australia, The comparative analysis of zooplankton in some tropical and temperate freshwater waters showed that tropical zooplankton had some unique characteristics[1]. For example, the difference in rotifer species composition in tropical, subtropical, and temperate regions was mainly due to the distribution of a few genera with regional restrictions; Another example, in tropical waters a low diversity of zooplankton tended to be seen, with the number of main species decreased, and tended to be small. Large Cladocera were common in the temperate zone, but less in the tropical zone[2]. Lingnan is located in the tropics and subtropics. Through the investigation and sampling of zooplankton in the urban lakes of Lingnan, the species composition, abundance, dominant species, dominance of zooplankton were preliminarily understood. It showed that the characteristics of zooplankton in the urban lakes of Lingnan were similar to those in the tropics but different from those in the temperate zone, and the reasons for the differences in the distribution of zooplankton were analyzed.

\section{Materials and methods}

Qualitative and quantitative sampling of zooplankton: the rotifer was qualitatively dragged with No. $25(64 \mu \mathrm{m})$ plankton net, and the quantitative sample was collected with $1 \mathrm{~L}$ water sampler, fixed with $5 \%$ formalin on site, brought back to the laboratory for static sedimentation, then concentrated to $25 \mathrm{ml}$, and the number of zooplankton was counted under a microscope. Macrozooplankton was qualitatively dragged with No. $13(113 \mu \mathrm{m})$, and quantitative samples were collected from the surface with a $5 \mathrm{~L}$ water sampler, filtered and concentrated with No. 25 net, and fixed with 5\% formalin on the spot. After concentration, species identification and counting were carried out by dissecting microscope in the laboratory.

\section{Distribution characteristics of zooplankton in tropical shallow urban lakes}

\subsection{Distribution characteristics of zooplankton species}

Brachionus, Trichocerca, and Lecane were the three most abundant genera of rotifers in urban lakes of Lingnan, accounting for $49 \%$ of the rotifer species. There were 17 species of Brachionus, among which Brachionus diversicornis, B. forficula, B. calyciflorus, B. angularis, $B$. urceus, B. falcatus, B. budapestinensis were the most widely distributed; There were 14 species of Trichocerca, including Trichocerca capucina, T. cylindrica, T. pusilla, $T$. stylata et al; There were 15 species of Lecane, including Lecane luna, L. ploenensis, L. monosytla lunaris, L. quadridentata, and L. bulla; Besides, Keratella valga, K. cochlearis, Anuraeopsis fissa, Polyarthra trigla, Filinia longiseta, F. mairei, Asplanchna brightwelli, and A. priodonta, were also widely distributed; Synchaeta was also distributed; Cephalodella and Notholca were uncommon.This was consistent with the current studies on tropical zooplankton. Brachionus, Trichocerea, and Lecane were

Corresponding author: gzcgr@qq.com 
mainly distributed in tropical and subtropical regions, and account for the majority of rotifer species in this region[3], however, in temperate regions, there were only a few species; Keratella, Cephalodella, Notholca, and Synchaeta were also distributed in tropical and subtropical regions, and some species were widely distributed or endemic to the region (e.g. K. Tropica), but most species were mainly distributed in the temperate zone[4].

There were 20 species of Cladocera belonging to 14 genera and 7 families. The species composition of Cladocera were mainly eurythermal and some warm species. The common species were Moina micrura, Bosmina longirostris, Diaphanosoma leuchtenbergianum, Ceriodaphnia cornuta, and Bosminopsis deitersi et al. Copepoda including Calanoida, Harpacioida, and Cyclopoida were found in 4 families, 12 genera, and 15 species. The species composition of Copepoda reflected the typical characteristics of the Lingnan region, including Argyrodiasptomus ferus, A. specillodactylus, Heliodiaptomus serratus, and other species belong to southern China, especially Argyrodiasptomus ferus which was larger and liked clear water, was a unique species in Lingnan. Mesocyclops thermocyclopoides, Thermocyclops taihokuensis, and A. specillodactylus were the common species.

\subsection{Abundance characteristics of zooplankton}

Rotifera was dominant in Lingnan urban lakes, the abundance of Rotifera accounted for $(79.63 \pm 2.48) \%$ of zooplankton abundance, while the relative abundance of Cladocera and Copepoda which were relatively large were low and the abundance of Cladocera and Copepoda were $(1.37 \pm 0.21) \%,(5.58 \pm 1.07) \%$ respectively. Some studies had shown that Rotifera, small Cladocera, and Nauplius were the main zooplankton in tropical and subtropical zones compared with temperate zones [5]. The abundance of zooplankton ranged from 51.20 to $1450.00 \mathrm{ind} \cdot \mathrm{L}^{-1}$, and the average abundance was $(427.29$ \pm 38.36 ) ind $\cdot \mathrm{L}^{-1}$. Among them, the abundance of Rotifera ranged from 17.60 ind $\cdot \mathrm{L}^{-1}$ to $1130.00 \mathrm{ind} \cdot \mathrm{L}^{-1}$, and the average abundance was $(345.95 \pm 32.33)$ ind $\cdot \mathrm{L}^{-1}$; The abundance of Cladocera ranged from 0.80 to 30.00 ind $\cdot \mathrm{L}^{-1}$, and the average abundance was $(5.89 \pm 0.97)$ ind $\cdot \mathrm{L}^{-1}$; The abundance of Copepoda ranged from 1.00 to 130.00 ind $\cdot L^{-1}$, and the average abundance was $(23.66 \pm 4.83)$ ind $\cdot \mathrm{L}^{-1}$; The average abundance of Nauplius ranged from 1.20 to 240.00 ind $\cdot \mathrm{L}^{-1}$, and the average abundance was $(58.40 \pm 8.50)$ ind $\cdot \mathrm{L}^{-1}$. In addition, the abundance of zooplankton was affected by aquatic plants and fish to a certain extent. In lakes with aquatic plants, the relative abundance of Cladocera and Copepoda that large zooplankton was higher, while in lakes with fish culture, Rotifera that small zooplankton was the dominant species.
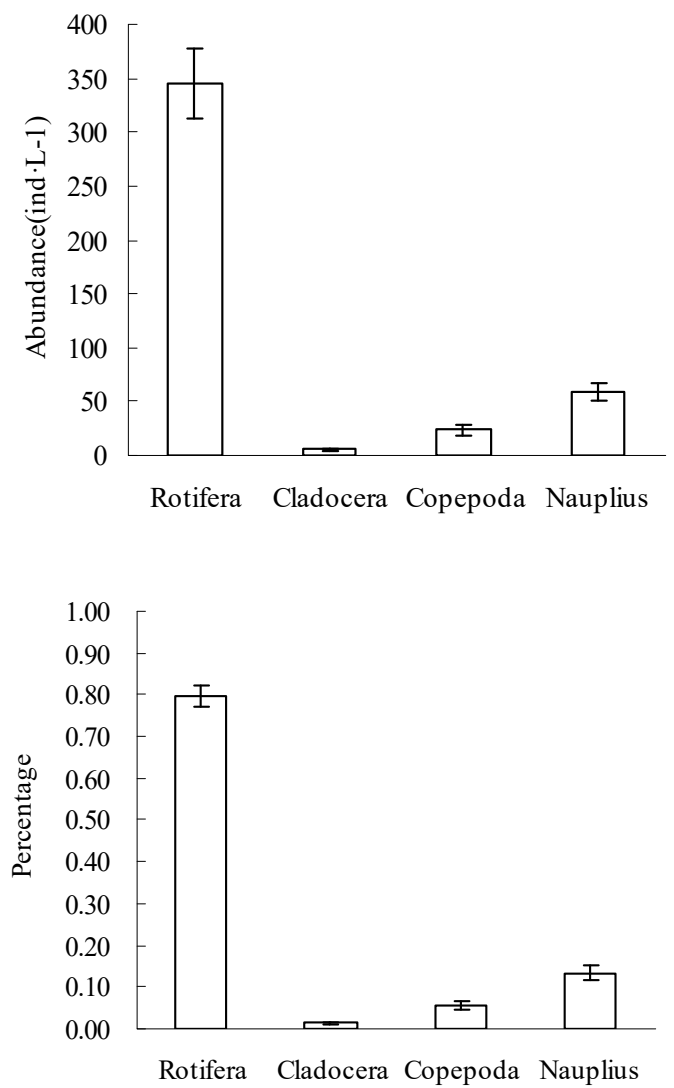

Figure 1. Average and relative abundance zooplankton in urban lakes of Lingnan $( \pm \mathrm{SE})$

\subsection{Dominant species of zooplankton}

The dominant species of zooplankton in Lingnan urban lakes were Polyarthra trigla, Schizocerca diversicornis, Brachionus forficula, Brachionus calyciflorus, Brachionus angularis, Anuraeopsis fissa, Trichocerca capucina, Filinia longiseta, Asplanchna brightwelli, and Nauplius et al, which could be found in most lakes with high abundance.

Table 1. The dominant species of zooplankton in urban lakes of Lingnan

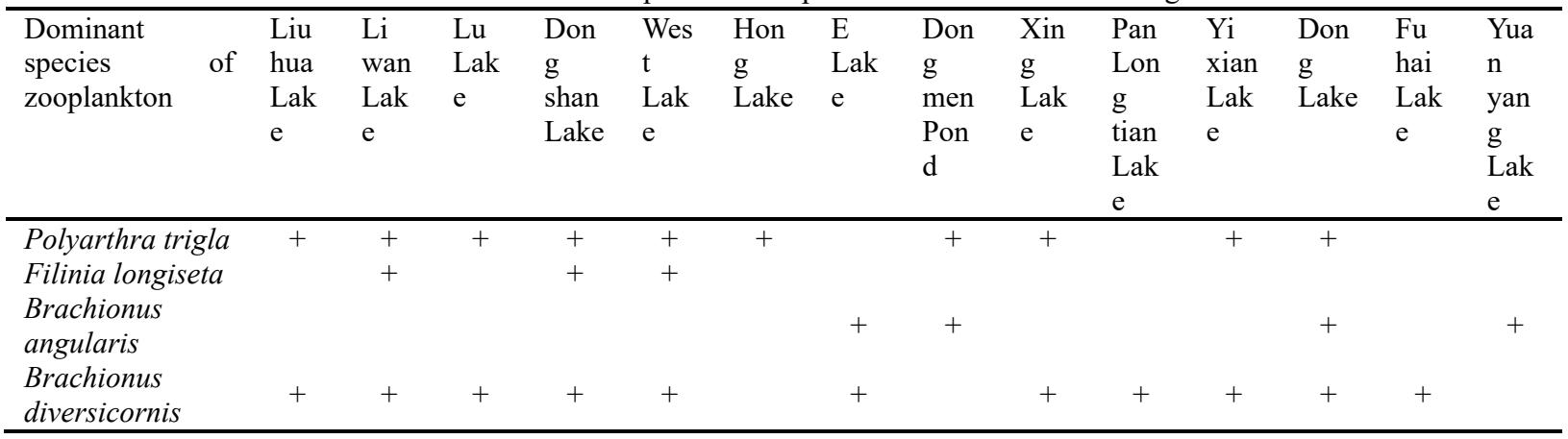




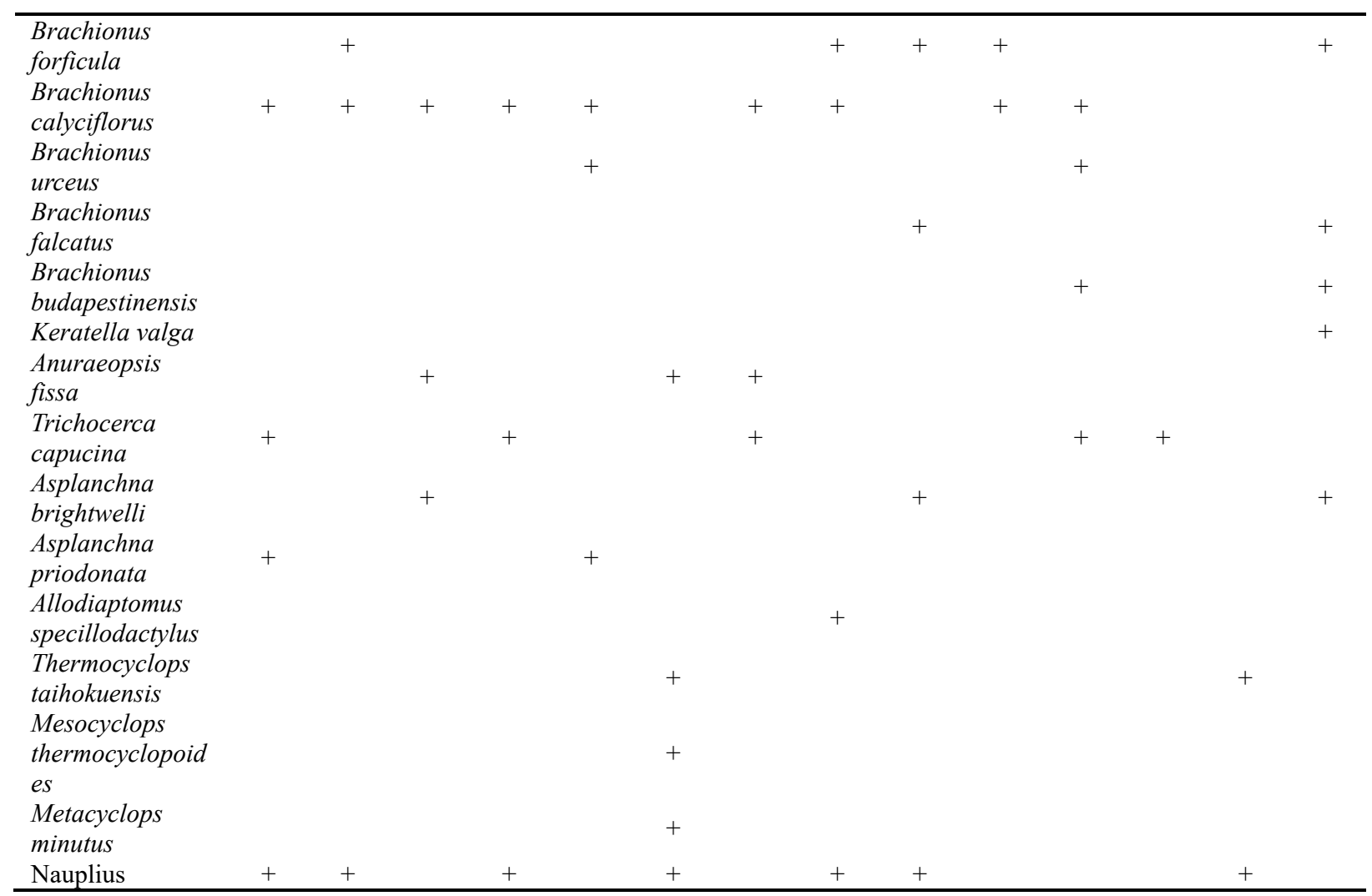

\section{Zooplankton in typical tropical shallow urban lake}

The distribution of zooplankton in Huizhou West Lake was the same as that in other tropical and subtropical regions [6]. Brachionus, Trichocerca, and Lecane were detected more, accounting for $41.5 \%$ of the total species. The detected species were mainly eurythermic species and some thermophilic species. In the distribution of abundance, the total abundance was higher in May and September when the temperature was higher. Water temperature could directly affect the growth, development, community composition, and quantity of zooplankton. According to the long-term fixed-point observation of Wuhan East Lake, the peak of Rotifera population generally appeared at the water temperature above $20^{\circ} \mathrm{C}$. The abundance of macrozooplankton was higher in September, and the water temperature may be more suitable in September, and the food in lake was also more abundant. Some research compared the temperate and tropical water bodies and concluded that when the water temperature exceeds $20^{\circ} \mathrm{C}$, the number of Daphnia was usually very low [7].

Besides, fish also had a greater impact on zooplankton, and the predation of fish on Cladocera had obvious selectivity on individual size. Generally, the larger zooplankton was preferred under the same energy consumption. When the fish density was high, the species and abundance of Cladocera with larger individuals were very low [8]. There were many fishes in Huizhou West Lake, including silver carp, bighead carp, and tilapia. In addition to cultured fishes, wild fish in natural waters usually had a large population, these fishes were small and could reproduce all year round. They mainly fed on zooplankton, Cladocera were the main food of these fishes. It was studied the effect of silver carp filter-feeding on Cladocera, and found that the effect on large Cladocera such as Daphnia was more significant than that on small Cladocera[9]. Large Cladocera was the first choice of predators and was in a disadvantageous position in the competition with silver carp and bighead carp for phytoplankton filtration, which was not conducive to the accumulation of its population. Therefore, the predation behavior of fish or invertebrates reduced the pressure of competition of Rotifera and small Cladocera $(<1 \mathrm{~mm})$ to a certain extent[10], so small species were dominant in species composition and abundance.

\section{Analysis of zooplankton distribution in tropical shallow urban lakes}

During the sampling period, the water temperature of the lakes ranged from $26.5{ }^{\circ} \mathrm{C}$ to $32.30{ }^{\circ} \mathrm{C}$, and the average water temperature was $(30.12 \pm 1.25){ }^{\circ} \mathrm{C}$. The analysis showed that Brachionus, Trichocerca, and Lecane, which were mainly distributed in tropical and subtropical regions, were dominant in species composition and abundance of rotifers. The lower abundance of Cladocera was also affected by the water temperature which was an important factor that affected the horizontal distribution of zooplankton. Most species of zooplankton were algophagous species, including phytoplankton, bacteria, and organic debris, Therefore, there was more filter-feeding zooplankton in phytoplankton rich waters. The relationship between Cladocera abundance and 
chlorophyll content was not obvious, which was possible that cyanobacteria were the dominant species of phytoplankton in urban lakes so that not conducive to the in Lingnan had fish, except for a few lakes where fish grew and distributed naturally, most of the fish in lakes artificially raised, which had a certain impact on the lake ecosystem especially the zooplankton. The results showed that the community structure and size composition of zooplankton could be greatly changed by fish predation[12]. The predation of zooplankton mainly depended on size selection and prey visibility, usually the first choice was large zooplankton in the selection of size and shape, and the order of choice was Cladocera, Daphnia, Cyclops with the same size. It usually led to the dominance of large species in zooplankton community being replaced by small species. In many water bodies, the dominance of small zooplankton increased due to the introduction of particulate feeding fish or the increase of fish biomass. The abundance and relative abundance of Cladocera and Copepoda were generally lower in the lakes where fish was farmed, fish predation had a certain impact on the structure and size composition of zooplankton community. In combination, higher water temperature, food restriction, and higher predation pressure of fish might explain the low abundance of macrozooplankton.

Almost all young fish and many adult fish ate zooplankton, and some of them would selectively prey on larger species. The existence of a large number of plankton feeding fish would greatly reduce the number and size of zooplankton. It was shown that tropical fish species were more abundant, large carnivorous fish was less, while small or waiting predatory fish were generally more, omnivorous fish was often dominant [13]. Fish in temperate lake reproduced once a year, and many tropical lake fish reproduced all the year round, which formed predation pressure on zooplankton all the year. Omnivorous fish species were not affected by the single food of zooplankton, and were not easy to be preyed on by small carnivorous fish, so fish in tropical lakes was small, but the density was large. Most of the zooplankton in the tropics was Rotifera, small Cladocera, and Nauplius, and zooplankton species with short life cycle and low filtration rate had little ability to control phytoplankton.

In addition, aquatic vegetation was one of the important factors that affected the species composition, density, and diversity index of zooplankton [14]. Aquatic vegetation could provide shelter for zooplankton, but in tropical lakes, with the restoration of aquatic vegetation, a large number of omnivorous fish proliferated which increased the predation pressure on zooplankton. Aquatic vegetation not only provided shelter for zooplankton, but also provided a place for the breeding of omnivorous fish, which indirectly increased the predation pressure on zooplankton. It was believed that in the process of restoration of tropical lakes, small and medium-sized filter fishes were on the dominant and concentrated in aquatic vegetation, and the protection of aquatic vegetation for large zooplankton was limited. It was suggested that phytoplankton feeding fish might be a more suitable tool for biological manipulation in tropical feeding of Cladocera and other large zooplankton[11]. Small Rotifera became relatively important and the dominant group of a water body. Most of the urban lakes and subtropical regions because of the small number and smaller size of Cladocera. The ecological restoration of typical tropical shallow urban lake showed that the combination of aquatic vegetation restoration and fish regulation was an effective measure for the control of tropical shallow eutrophic urban lake[15].

\section{Conclusion}

The abundance of Rotifera accounted for (79.63 \pm $2.48) \%$ of zooplankton abundance in urban lakes of Lingnan, while the relative abundance of Cladocera and Copepoda which were relatively large were low and the abundance of Cladocera and Copepoda were $(1.37 \pm$ $0.21) \%$, (5.58 \pm 1.07$) \%$ respectively. Among them, Brachionus, Trichocerca, and Lecane occupied almost $49 \%$ of the rotifer species in urban lakes of Lingnan. Rotifera was dominant of zooplankton abundance in shallow urban lakes of Lingnan, while Brachionus, Trichocerca, and Lecane were the three most abundant genera of rotifers. Rotifera, small Cladocera, and Nauplius were the main zooplankton, the dominant zooplankton tended to have a small individual population. The abundance of large Cladocera was low, which was affected by high water temperature, food restriction, and predation pressure of fish.

\section{Acknowledgments}

This work was supported by the project of Department of Education of Guangdong Province (Grant No. 20130201018).

\section{References}

1. Dumont H J, Hydrobiologia 104, 19-30(1983)

2. Fernando $\mathrm{C} \mathrm{H}$, Int Review Ges Hydrobiol 76, 149-167(1980a)

3. Segers H, Hydrobiologia 446/447, 233-246(2001)

4. Green J., Hydrobiologia 272, 13-26(1994)

5. Dumont H J, Hydrobiologia 272, 27-38(1994)

6. Dussart B H, Fernando C H, Matsumura-Tundisi T, et al, Hydrobiologia 113, 77-91(1984)

7. Gillooly J F, Dodson S I, Limnol Oceanogr 45, 22-30(2000)

8. Swiercowski A, Godlewska M, Poltorak T, Aquat Living Resour 13, 373-377(2000)

9. Domaizon I, Devaux J, life Sciences 322, 621-628(1999)

10. Korponai J, Paulovits G, Matyas K, Hydrobiologia 504, 193-201(2003)

11. Guangrong Chen, IOP Conf. Series: Earth and Environmental Science 526, 012028(2020)

12. Brooks J, Dodson S, Science 150, 28-35(1965) 
13. Fernando C H, Hydrobiologia 272, 17-38(1994)

14. Schriver P, Bogestrand J, Jeppesen E, Søndergaard M, Freshwater Biology 33: 255-270(1995)
15. Guangrong Chen, IOP Conf. Series: Earth and Environmental Science 508, 012110(2020) 